\title{
Temporal changes in the cell population and wound healing-related gene expression in deep partial-thickness burn wound model
}

Hui-fang Guo ${ }^{1,2}$, Razana Mohd. Ali ${ }^{3}$, Roslida Abd. Hamid', Sui Kiat Chang ${ }^{4}$, Mohammed Habibur Rahman ${ }^{5}$, Zaida Zainal ${ }^{6}$ and Huzwah Khaza'ai ${ }^{1 *}$ (i)

\begin{abstract}
Background: Burns are injuries that lie on the skin or other organic tissues caused by exposures to the heat, electricity, chemicals or ionizing radiation. The present study was carried out to record temporal changes in the cell population and wound healing-related gene expression in rats with deep partial-thickness burn.

Methods: Burn wound was induced on the dorsal part of Sprague-Dawley rats using temperature-regulated 20-mm wide aluminum head heating device. Animals were then sacrificed on days three, seven, 11, 14 and 21 post-burn, respectively. Half of the wounded skin tissues were dissected and fixed in buffered neutral formalin for Hematoxylin \& Eosin (H\&E) staining, and the other half were cut off and stored in $-20^{\circ} \mathrm{C}$ for real-time PCR analyses.

Results: The number of adipose cells was found to be maximal on the 3rd day post-burn, and it gradually decreased over time and completely disappeared on day 11 post-burn. The maximum number of neutrophils were found to be on the 3rd and 14th day post-burn, while the maximum number of myofibroblasts were found on the 11 th day post-burn. The number of lymphocytes did not change too much during the whole healing process. At the gene expression level, the expression pattern of inflammation-related genes including IL-6, TNF- $a$ and iNOS were similar, which was found to be increased from day 3 to day 11 and decreased thereafter. Angiogenesis related genes including both VEGF-A and TGF- $\beta 1$ showed a same expression pattern, both of which were slightly increased from day 3 to day 14 and smoothly decreased on day 21 post-burn. Matrix re-modeling related genes including MMP-2, TIMP-2 and Collagen-1 changed over time synchronously, where they all persistently increased from day 3 till day 14, then slightly declined on day 21 post-burn.
\end{abstract}

Conclusion: The present study revealed the changes in the cell population and expression profile of wound healing-related genes in deep partial-thickness burn, which could provide a cellular and genomic basis for the future research of burn injuries.

Keywords: Burn, Cell population, Gene expression, Temporal changes, Wound healing

\footnotetext{
* Correspondence: huzwah@upm.edu.my

'Department of Biomedical Sciences, Faculty of Medicine and Health

Sciences, Universiti Putra Malaysia, Serdang, Selangor, Malaysia

Full list of author information is available at the end of the article
}

(c) The Author(s). 2020 Open Access This article is distributed under the terms of the Creative Commons Attribution 4.0 International License (http://creativecommons.org/licenses/by/4.0/), which permits unrestricted use, distribution, and reproduction in any medium, provided you give appropriate credit to the original author(s) and the source, provide a link to the Creative Commons license, and indicate if changes were made. The Creative Commons Public Domain Dedication waiver (http://creativecommons.org/publicdomain/zero/1.0/) applies to the data made available in this article, unless otherwise stated. 


\section{Introduction}

Burn is a common injury that may be caused by exposure to heat, electricity, chemicals and or ionizing radiation (Lin et al. 2011). According to the structural-anatomical classification, burns are identified into three categories of increasing depth of the thermal damage (Monstrey et al. 2008). They are superficial burn (only the epidermis is involved), partial-thickness burn (both the epidermis and dermis are affected) and full-thickness burn (the injury extends to all layers of the skin) (Kagan et al. 2009).

Healing of burn wound is a complicated process consisting of three continuous and overlapping stages known as inflammation, proliferation and tissue remodeling (Velnar et al. 2009). Coagulation cascade is activated immediately after injury. Platelets are entrapped into the wound and secrete several mediators of wound healing such as platelet-derived growth factor (PDGF) and transforming growth factor- $\beta$ (TGF- $\beta$ ), which can attract and recruit leukocytes to the site of injury to debride the wound (Harper et al. 2014). In the early stage of inflammation, neutrophils are the predominant cells to be present. They destroy bacteria, foreign particles, damaged tissue and protect the tissue from infection. Proliferation stage continues for about two weeks. At this stage, new blood vessels are formed to provide nutrition and oxygen to the growing tissue, fibroblasts migrate into the wound site to proliferate and produce procollagen. In the meanwhile, keratinocytes migrate into the wound area and proliferate to cover the wound ( $\mathrm{Li}$ et al. 2007). The final stage of wound healing is tissue re-modeling, which may last for one to two years (Velnar et al. 2009). One of the important features of the re-modeling period is collagen deposition. Through the balance between synthesis and degradation, the amount of collagen is strictly regulated. Matrix metalloproteinases (MMPs) are responsible for the degradation of collagen and their catalytic activities are inhibited by tissue inhibitors of metalloproteinases (TIMPs). Any distortions in the process may lead to poor healing processes such as chronic wounds, or excessive healing, including hypertrophic scars and keloids.

From the above background, Wound healing requires coordination of several cell types including keratinocytes, fibroblasts, endothelial cells, macrophages, and platelets, the migration, infiltration, proliferation, and differentiation of which eventually lead to inflammatory reactions, new tissue formation and wound closure. This complex process is carried out and regulated by the same complex signal transduction network involving numerous growth factors, cytokines, chemokines, and extracellular matrices (Werner and Grose 2003).

Upon understanding of the pathophysiology of burn wound healing, studies were continued to probe into gene expression changes in burn injuries to explore the gene expression in Sprague-Dawley rats with full-thickness scald burn by DNA microarray analysis (Spies et al. 2002). Burn wound healing-related genes expression in the skin of BALB/c mice with burn wound was also investigated (Kubo et al. 2014). However, literature searches yielded no report on temporal expression of wound healing-related genes in deep partial-thickness burn in rats so far. Thus, this work examined the temporal expression pattern of wound healing related genes as well as the cell kinetics of burned dermal tissues in Sprague-Dawley rats.

\section{Materials and methods \\ Animals}

Thirty male Sprague Dawley (SD) rats weighing between $250 \pm 50 \mathrm{~g}$ were used for this study. They were all kept in a temperature-controlled environment $\left(25 \pm 1^{\circ} \mathrm{C}\right)$ and fed ad libitum with standard rat chow and water daily. Wood shavings were used as bedding and changed twice a week. All animal experimental procedures were approved by the Institutional Animal Care and Use Committee, Universiti Putra Malaysia (UPM), Malaysia (Ref: AUP/ R095/2014).

\section{Burn wound model}

The experiment was conducted in the Animal House of Faculty of Medicine and Health Sciences, Universiti Putra Malaysia, using male Sprague-Dawley rats (8-10 weeks, weighing $250 \pm 50 \mathrm{~g})$. The method described by our previous study (Guo et al. 2017) was used to induce the burn injury. The procedure was essentially as follows: Rats were acclimatized for one week prior to the experiment. After that, they were weighed and anesthetized by using $15 \mathrm{mg} / \mathrm{kg}$ Xylazine $^{\oplus}$ (Troy Laboratories, Australia) and $75 \mathrm{mg} / \mathrm{kg}$ Ketamine ${ }^{\bullet}$ (Troy Laboratories, Australia) injections by intramuscular route. Then, animal's dorsum was shaved by electric clippers and commercial depilatory cream $\left(\right.$ VEET $^{\mathrm{TM}}$ ) was used for depilation. Burn injuries were initiated by a temperatureregulated aluminum head $20 \mathrm{~mm}$ in diameter with a contact temperature of $70{ }^{\circ} \mathrm{C}$. It was applied for $10 \mathrm{~s}$ to produce a deep partial-thickness burn. The whole pressure exerted on the rat dorsal skin was weighing $300 \mathrm{~g}$. Wounds were created at 5-min intervals to allow the aluminum head to recover to $70{ }^{\circ} \mathrm{C}$. The general appearance of the wound immediately after inducing burn was shown in Fig. 1. The burn depth was then confirmed from samples that were collected day 3 post-burn by hematoxylin and eosin (H\&E) staining.

\section{Treatment of wounds}

Animals were housed in individual cages after having been received experimental burn wounds. After having lapse of five minutes, induced wounds were irrigated by spraying sterile saline solution and dried using sterile gauze. During the whole experimental period, the experimental wounds were kept uncovered. 


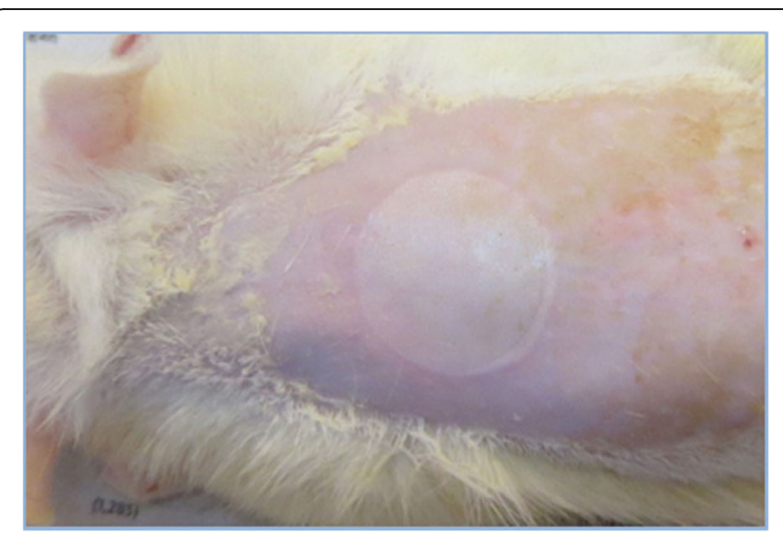

Fig. 1 General appearance of the wound immediately after inducing burn. The burned skin showed notable paleness. The shape was round with $20 \mathrm{~mm}$ in diameter and the boundary between the burned skin and normal skin was found to be well demarcated

\section{Sample collection}

On day three, seven, 11, 14 and 21 post-burn, six animals were anesthetized and sacrificed respectively, the whole damaged skin tissue was cut off and washed thoroughly with physiological saline $\left(4{ }^{\circ} \mathrm{C}\right)$. Then, half of the tissue was fixed in $10 \%$ formaldehyde for histological studies, and the other half was stored in RNA stabilization reagent at $-20^{\circ} \mathrm{C}$ for RNA extraction.

\section{Histological assessment}

The methods of our previous study (Guo et al. 2017) were used to carry out this experiment. After animals were sacrificed, blocks of half of the damaged skin tissue was cut off and fixed in 10\% formaldehyde. The samples were then processed through graded alcohol, chloroform, infiltrated with molten wax and embedded in paraffin in Paraffin Embedding Station (Leica EG1600, German). Sections were cut at $5 \mu \mathrm{m}$ thickness with Rotary Microtome (Leica RM 2135, German) and dried at room temperature for at least one day. Prior to dyeing, the slides were placed in an oven (Venticell, UK) at $60^{\circ} \mathrm{C}$ for an hour to melt the paraffin. The Hematoxylin \& Eosin (H\&E) staining was carried out in Autostainer (Prisma E2S, Japan). Histological changes in the stained sections were studied under an optical microscope (Leica Microsystems AG, Germany).

\section{Cell counting}

Histological micrographs of samples on day three, seven, 11,14 and 21 post-burn were captured with an optical microscope (Leica Microsystems AG, Germany) at $400 \mathrm{x}$ magnification. Six photographs from the area (approximately halfway between the deepest layer of the wound and the dermis) were used for cell counting. Different types of cells including adipose cells, neutrophils, lymphocytes and myofibroblasts were counted. The identification of these cells was based on the morphological appearance of the cells (Fig. 2). The average number of cells counted from six photomicrographs were used for this analysis.

\section{RNA extraction}

RNA from the samples on day three, seven, 11, 14 and 21 after burn was extracted with RNeasy Fibrous Tissue Kit (Cat. No.74704, Qiagen, Germany) according to manufacturer's protocols. The purity and quantity of RNA were determined using a NanoVue Plus Spectrophotometer (GE Healthcare, UK). RNA with a ratio of absorbance between 1.8 and 2.1 at $260 \mathrm{~nm}$ and $280 \mathrm{~nm}$ was considered with high purity.

\section{RT-PCR}

Real-time PCR was carried out on LightCycler 480 (Roche, Basel, Switzerland) using LightCycler 480 Probers Master (Cat. No. 04887301001. Roche, Switzerland) following manufacturer's instructions with slight modifications. The isolated RNA was then reverse transcribed to cDNA by employing real-time polymerase chain reaction (RT-PCR). GAPDH (Glyceraldehyde-3-phosphate dehydrogenase)

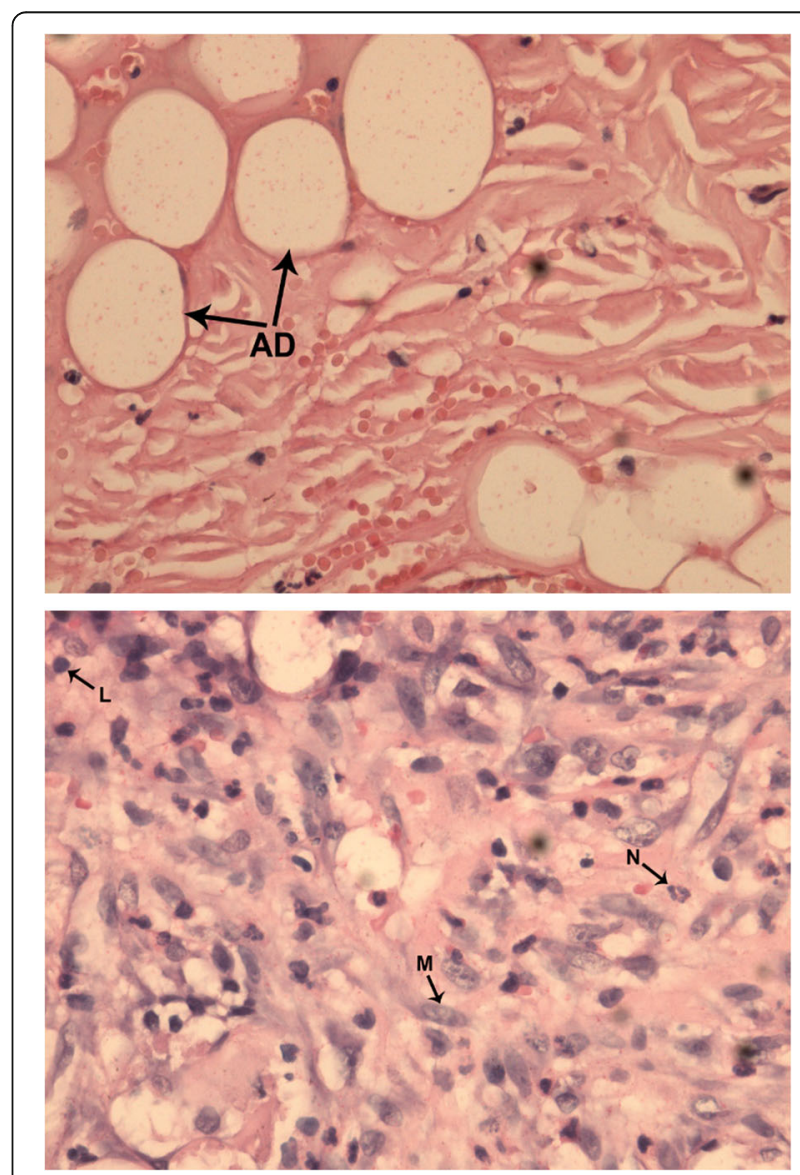

Fig. 2 Photomicrographs of the wound sections showing cells that were identified and counted. AD: adipose cells; N: neutrophils M: myofibroblasts; L: lymphocytes (H\&E staining, 400X) 
was included as the reference gene for normalization of the target genes and for compensation of inter-PCR variation between each RT-PCR experiment.

\section{cDNA synthesis}

The cDNA synthesis was carried out using Transcriptor First Strand cDNA Synthesis Kit (Cat. No.04897030001 Basel, Switzerland) following manufacturer's protocol.

\section{RT-PCR data analysis}

Eight wound healing related genes as well as three housekeeping genes were analyzed and the primer used was shown in Table 1 . The expression level of both target and house-keeping genes were calculated utilizing the $\mathrm{Ct}$ values and the corresponding standard curve, where y-axis represented Ct values while $\mathrm{x}$-axis represented the logarithms of cDNA amount. As a result, the amount of target gene could have been read through their $\mathrm{Ct}$ values. To have the normalized values, the amount of target gene was divided by that of the reference genes. The geometric mean of three reference genes was used as the final normalized value. Log 2 of this value was shown in the graph and used to compare with each other. In each independent experiment, target

Table 1 Primers used in Q-PCR

\begin{tabular}{|c|c|c|}
\hline S. no. & Gene & Primer \\
\hline \multirow[t]{2}{*}{1} & \multirow[t]{2}{*}{ IL-6 } & Forward: 5' -CCCTTCAGGAACAGCTATGAA- 3' \\
\hline & & Reverse:5' -ACAACATCAGTCCCAAGAAGG- 3' \\
\hline \multirow[t]{2}{*}{2} & \multirow[t]{2}{*}{ TNF-a } & Forward: 5' -GCCTCTTCTCATTCCTGCTC- 3' \\
\hline & & Reverse: 5' -GAGCCCATTTGGGAACTTCT- 3' \\
\hline \multirow[t]{2}{*}{3} & \multirow[t]{2}{*}{ iNOS } & Forward: 5' -CAGGTTGAGGATTACTTCTTCCA- 3' \\
\hline & & Reverse: 5' -TGTCAGAGTCTTGTGCCTTTG- 3' \\
\hline \multirow[t]{2}{*}{4} & \multirow[t]{2}{*}{ VEGF-A } & Forward: 5' -CGGAGAGCAACGTCACTATG- 3' \\
\hline & & Reverse: 5 '-TGGTCTGCATTCACATCTGC- 3' \\
\hline \multirow[t]{2}{*}{5} & \multirow[t]{2}{*}{ TGF- $\beta 1$} & Forward: 5' -CCTGGAAAGGGCTCAACAC -3' \\
\hline & & Reverse: 5' -CAGTTCTTCTCTGTGGAGCTGA- 3' \\
\hline \multirow[t]{2}{*}{6} & \multirow[t]{2}{*}{$M M P-2$} & Forward: 5' -TTCTGTCCCGACCAAGGA- 3' \\
\hline & & Reverse: 5' -GGTGTAGATAGGGGCCATCA- 3' \\
\hline \multirow[t]{2}{*}{7} & \multirow[t]{2}{*}{ TIMP-2 } & Forward: 5' -CGTITGCAATGCAGACGTA- 3' \\
\hline & & Reverse: 5' -GATGGGGTTGCCATAGATGT- 3' \\
\hline \multirow[t]{2}{*}{8} & \multirow[t]{2}{*}{ Collagen-1 } & Forward: 5' -CAACAAGCATGTCTGGTTAGGA-3' \\
\hline & & Reverse: 5' -CACCCCTTCTGCGTTGTATT- 3' \\
\hline \multirow[t]{2}{*}{9} & \multirow[t]{2}{*}{ EGFR } & Forward: 5' -TCCATCCTAGAGAAAGGAGAGC-3' \\
\hline & & Reverse: 5' -GCGGCTATCAGCATCTATCAT-3' \\
\hline \multirow[t]{2}{*}{10} & \multirow[t]{2}{*}{ PGK1 } & Forward: 5' -GATGGGCTTGGACTGTGGTA- 3' \\
\hline & & Reverse: 5' -AACAGGACCGTTCCAAACAA- 3' \\
\hline \multirow[t]{2}{*}{11} & \multirow[t]{2}{*}{ PSMB2 } & Forward: 5' -GAGGGCAGTGGAGCTTCTTA- 3' \\
\hline & & Reverse: 5' -AGGTGGGCAGATTCAAGATG- 3' \\
\hline \multirow[t]{2}{*}{12} & \multirow[t]{2}{*}{ GAPDH } & Forward: 5'-AATGTATCCGTTGTGGATCTGA - 3' \\
\hline & & Reverse: 5' - GCTTCACCACCTTCTTGATGT - 3' \\
\hline
\end{tabular}

and reference gene cDNA were derived from similar extracted RNA and run simultaneously in the RT-PCR. Three independent experiments were performed in triplicate.

\section{Statistical analysis}

The averages of three independent experiments used for statistical analysis were calculated in each group and was done by one-way analysis of variance (ANOVA) using the Statistical Package for the Social Sciences (SPSS) Version 22 software (SPSS Inc., Chicago, IL, USA). When $p$-values were $<0.05$, the significance of difference between groups was estimated by Bonferroni's multiple comparisons tests. All data were expressed as mean \pm S.E.M.

\section{Results}

Temporal changes of cells involved in deep partialthickness burn wound healing

The number of adipose cells, neutrophils, lymphocytes and myofibroblasts in the skin that were stained with H\&E with deep partial-thickness burn was counted in days post-burn, as shown in Table 2. Results showed that the maximum amounts of adipose cells were estimated on day-three postburn. Afterwards, its number was found to be significantly decreased $(p<0.05)$ with time and totally disappeared on day 14 post-burn. Presence of neutrophils was noticed at a high level on day three post-burn, then the number was gradually decreased on day 7 and 11 post-burn. Nonetheless, on day 14 post-burn, the number of neutrophils showed a significant decrease $(p<0.05)$. Finally, its number reduced to a lowest level on day 21 post-burn. Unlike neutrophils, there were no lymphocytes observed on the third day post-burn. The number of lymphocytes increased steadily form third day to seventh and reached its maximum number on day 11 and gradually decreased on day 21 post-burn. Compared to those of lymphocytes, there was no myofibroblastic proliferation observed on the third day post-burn. However, from seventh day onward, the number of myofibroblasts was found to be significantly increased $(p<0.05)$ and reached its maximum level on day

Table 2 Temporal changes of the number of different cell types in the skin tissue with deep partial-thickness burn

\begin{tabular}{|c|c|c|c|c|}
\hline \multirow{2}{*}{$\begin{array}{l}\text { Day } \\
\text { after } \\
\text { burn }\end{array}$} & \multicolumn{4}{|c|}{ Number of cells } \\
\hline & Adipocytes & Neutrophils & Lymphocytes & Myofibroblasts \\
\hline 3 & $11.17 \pm 2.30$ & $9.17 \pm 2.06$ & $0.00 \pm 0.00$ & $0.00 \pm 0.00$ \\
\hline 7 & $3.67 \pm 1.08^{a}$ & $6.11 \pm 1.68$ & $3.11 \pm 0.86$ & $18.78 \pm 5.28^{a}$ \\
\hline 11 & $0.50 \pm 0.50^{\mathrm{a}}$ & $5.50 \pm 0.56$ & $5.33 \pm 1.26$ & $51.50 \pm 5.12^{\mathrm{ab}}$ \\
\hline 14 & $0.00 \pm 0.00^{\mathrm{ab}}$ & $17.25 \pm 4.97^{\mathrm{bc}}$ & $4.34 \pm 0.60$ & $46.33 \pm 3.49^{\mathrm{ab}}$ \\
\hline 21 & $0.00 \pm 0.00^{\mathrm{ab}}$ & $2.11 \pm 0.74^{d}$ & $0.89 \pm 0.68$ & $18.56 \pm 1.92^{\mathrm{abd}}$ \\
\hline
\end{tabular}


11. Nonetheless, the number of myofibroblasts were then slightly decreased from day 14 , begun to show a slight decrease and reached to the lowest level on day 21 post-burn. By and large, by the 21st day post-burn, adipose cells disappeared from 21 days post-burn; the number of neutrophils and lymphocytes were also found to be decreased, but the number of myofibroblasts were found to remained constant throughout the study period.

\section{Temporal changes of wound healing related genes in deep partial-thickness burn wound healing}

The expression levels of eight wound healing related genes were examined on day three, seven, 11,14 and 21 post-burn to get a general view of their temporal changes during wound healing processes. The expression patterns of $I L-6, T N F-\alpha$ and $i N O S$ (Fig. 3a) were similar, where they were all found to be increased from day three to day seven and significantly increased $(p<0.05)$ from day 11 post-burn. The peak expression was observed during this period and then significantly decreased $(p<0.05)$ from day 14 . By day 21 , the expression levels of $I L-6$ and $i N O S$ were found to be slightly decreased while TNF- $\alpha$ expression was slightly increased. Angiogenesis related genes including both VEGF-A and TGF- $\beta 1$ (Fig. $3 \mathrm{~b}$ ) shared the same expression pattern. Both of them were slightly increased from day three to day 14 , and smoothly decreased from day 21 post-burn. Surprisingly, matrix re-modeling related genes including MMP-2, TIMP-2 (Fig. 3c) and Collagen-1 changed over time synchronously. Their expression all consistently increased from day three to day 14, then slightly declined on day 21 post-burn.

\section{Discussions}

Wound healing is a complex process and considered as one of the well-organized interactions between various types of tissues and cells (Oberyszyn 2008). In the present study, the number of adipose cells, neutrophils, lymphocytes and myofibroblasts in the healing process were evaluated. Adipose cells were examined and found to be the most abundant cells observed in the wound on the 3rd day post-burn. Besides, with the healing of the wound, the number of adipose cells gradually decreased and eventually disappeared. However, it remains unclear about the role of adipose cells in the wound healing.

Neutrophils were then examined and it turned out that the maximum number of neutrophils were found to be on the 3rd and 14th day post-burn. Neutrophils play an important role at the initial stage of wound healing. Shortly after burn, numerous neutrophils migrate to the wound area in response to platelet-derived chemokines to remove debris, foreign particles and bacteria. In addition, neutrophils can elaborate a number of growth factors for the next phases of wound healing and or
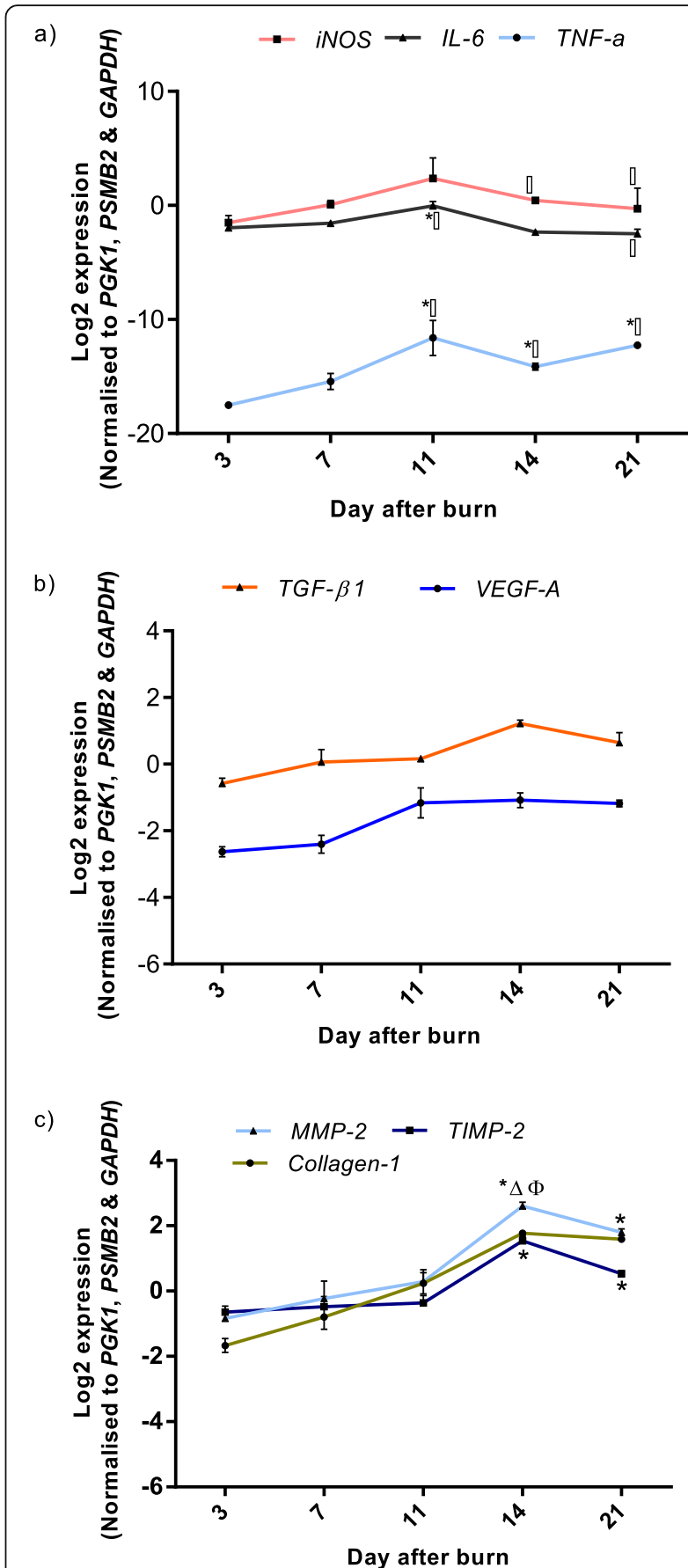

Fig. 3 Temporal changes of wound related genes in the skin tissue with deep partial-thickness burn. a Expression levels of IL-6, TNF-a and iNOS; $\mathbf{b}$ Expression levels of VEGF-A and TGF- $\beta 1$; $\mathbf{c}$ Expression levels of Collagen-1, MMP-2 and TIMP-2; Data were expressed as mean \pm S.E.M. ${ }^{*} p<0.05,{ }_{p} p<0.05,{ }_{p}^{\phi_{p}}<0.05,{ }_{p}<0.05$ compared to those recorded on day three, seven, 11 and 14, respectively

proliferative stages (Singer and Clark 1999). No wonder, the number of neutrophils was high on day three postburn. By day 14 post-burn, the crust on the surface of burn wound sloughed off, creating another open wound 
to the skin, thus a high number of neutrophils was noticed again in the skin tissue. After having completed of the above task, neutrophils usually disappeared due to cell apoptosis or may have been were phagocytized by macrophages (Enoch and Leaper 2005), which was consistent with the findings in the present study.

Lymphocytes, including thymocytes ( $\mathrm{T}$ cells) and B cells are also involved in wound healing processes. $\mathrm{T}$ cells appear in the wound after neutrophils and macrophages and play a regulatory role in wound healing (Park and Adrian Barbul 2004) and the role of B cells in wound healing is again poorly understood. In the present study, the maximum number of lymphocytes was found to be on the 11th day post-burn.

Fibroblasts usually entered in the wound on the 4th day post-burn. Once within the wound, fibroblasts proliferated and produced new extracellular proteins such as fibronectin, hyaluronan, collagen and proteoglycans ( $\mathrm{Li}$ et al. 2007). In addition, fibroblasts underwent phenotypic changes and differentiated into myofibroblasts to form a very strong adhesions to the surrounding granulation and provided the force for wound contraction (Grinnell 1994). As a result, the number of fibroblasts gradually increased from day three to day 11 post-burn. During the repair phase, the final stage of wound healing, most myofibroblasts disappear from the wound site through apoptosis or other cell death mechanisms to avoid the formation of hypertrophic scars or keloids (Park and Adrian Barbul 2004), which was in agreement with the present findings where the number of myofibroblasts significantly decreased on day 21 post-burn.

Wound healing related gene expression pattern in the healing process of deep partial-thickness burn was also evaluated in the present study. Inflammation was the first event in wound healing. Therefore, temporal changes of inflammation-related genes including IL-6 and TNF- $\alpha$ were first evaluated. Studies have shown that IL-6 is attractive to neutrophils and thus able of initiating wound healing (Barrientos et al. 2008). It was also reported that low level of TNF- $\alpha$ may promote wound healing by indirectly stimulating inflammation and increasing the production of growth factors generated by macrophages (Barrientos et al. 2008). Studies confirmed that expressions of $I L-6$ and $T N F-\alpha$ were elevated at the initial stages post-burn (Kubo et al. 2014). In the meanwhile, excessive inflammation resulted in chronic wounds or even lead to impaired wound healing. Therefore, consistent decrease of IL- 6 and TNF- $\alpha$ expression was to ensure no failure in the reconstruction and epithelialization processes in the burn wounds. Consistent results were also found in the present study, where the expression of IL- 6 and TNF- $\alpha$ in the skin tissue of rats with deep partial-thickness burn were increased from day three to 11 and then decreased from day 14 onward.
The inducible isoform of nitric oxide synthase (iNOS) catalyzes the production of nitric oxide by oxidizing Larginine to L-citrulline (Parihar et al. 2008). NO can interact with superoxide radical to produce peroxynitrite which is able to oxidize and nitrate tyrosine, tryptophan and guanine, causing oxidative stress in the wound area. Results obtained from the present study showed that $i N O S$ expression pattern was the same as that of $I L-6$, indicating a close relationship between $i N O S$ and inflammation. In fact, it had been proved that the activation of iNOS was induced by inflammatory cytokines (Guzik and Korbut 2003). What is more, in the transcriptional level, the expression of $i N O S$ was mainly regulated through inducible nuclear factor, $N F-K B$, which mediated a prototypical proinflammatory signaling pathway (Lawrence 2009). Therefore, the expression level of iNOS was changed with the change of the expression levels of both IL- 6 and TNF- $\alpha$.

VEGF-A is well-known for its role in stimulating angiogenesis. Studies have shown that serum level of VEGF-A in burn patients was increased from day seven to day 14 and then decreased from day 21 post-burn (Infanger et al. 2004), which is consistent with the findings on the expression of VEGF-A from the present study. TGF- $\beta 1$ has had impact multiple functions in wound healing. Besides promoting angiogenesis, it was reported to be involved in a number of processes such as inflammation, fibroblast proliferation, collagen synthesis, deposition and re-modeling of the new extracellular matrix (Penn et al. 2012). In addition, it was also reported that the expression of TGF- $\beta 1$ was increased in the hypertrophic scar tissue and fibroblasts (Wang et al. 2000). Therefore, it may be concluded that the increased expression of TGF- $\beta 1$ on day seven, 11 and 14 were closely related to its multiple functions in promoting wound healing. Decreased expression of TGF- $\beta 1$ on day 21 post-burn added an advantage for the wound to protect from scar formation.

Genes involved in tissue re-modeling including Collagen-1, MMP-2, and TIMP-2 were also elucidated in the present study. Collagen- 1 is the most abundant structural component in the dermal matrix. The results obtained have demonstrated that a low expression of Collagen-1 at the initial stage of healing, gradually accelerated expression in the middle of healing process and finally stable but relatively higher expression at the late stage of healing, which was coincided with an increase of the number of myofibroblasts that appeared in the wound site. It was reported that collagens were mainly produced by fibroblasts (Stamenkovic 2003). At the early stage of healing, most fibroblasts are destroyed due to the deep partial-thickness burn, and the results from the cell counting confirmed that no myofibroblast was found in the wound area. Therefore, the expression of Collagen-1 was mainly from 
the residual fibroblasts (Midwood et al. 2004). With the progress of wound healing, more myofibroblast were found to be proliferated and as a result, the expression of Collagen-1 was also increased. However, at the end of wound healing, the additional myofibroblasts were removed by apoptosis; correspondingly, the expression of Collagen-1 was also decreased. In addition, the Collagen-1 was one of the main structural proteins in the matrix (Pappas 2015). Thus, the higher level of expression was still maintained at the end of wound healing. MMPs are responsible for the degradation of the extracellular proteins (Fingleton 2008). The expression of $M M P-2$ from the present study was consistent with that of Collagen-1, which was involved in the tissue re-modeling. Interestingly, the expression pattern of TIMP-2 was also consistent with those of $M M P$-2. It is known that TIMPs are the natural inhibitor of MMPs (Birkedal-Hansen 1995). In addition, it is also found that both MMPs and TIMPs have selective affinities for each other (Lambert et al. 2004). TIMP-2 is 10-fold more effective than TIMP-1 to inhibit MMP-2 (De et al. 2005). Thus, the similarity of the expression pattern of TIMP-2 and MMP-2 might be due to the functional interactions.

\section{Conclusion}

By and large, it may be concluded from the above studies that the temporal changes in the cell population and expression pattern of wound healing related genes involved in inflammation, angiogenesis as well as tissue remodeling in wound healing. The results revealed the occurrence of the cell populations and expression pattern of these genes which were consistent with their role in the wound healing process. Finally, these findings provided a cellular and genomic basis for partial-thickness burn research using rats as an experimental model and may re-kindle interests pursuing more research in this field.

\section{Abbreviations \\ GAPDH: Glyceraldehyde-3-phosphate dehydrogenase; HE: Hematoxylin eosin; IL-6: Interleukin-6; iNOS: Inducible nitric oxide synthase; MMP: Matrix metalloproteinase; TGF: Transforming growth factor; TIMP: Tissue inhibitor of metalloproteinase; VEGF-A: Vascular endothelial growth factor-A}

\section{Acknowledgements}

The authors would like to express their grateful thanks to Leong Jia Wen for her help with Real-time PCR work.

\section{Authors' contributions}

$H K$ secured the research grant, conceived and designed the experiments. $\mathrm{H}$ $\mathrm{fG}, \mathrm{HK}, \mathrm{RMA}$ and $\mathrm{RAH}$ performed/consolidated the experiments and analyzed the data. SKC, HK, MHR, and ZZ prepared the manuscript. All authors read and approved the final manuscript.

\section{Funding}

The authors are grateful for the financial support from the Ministry of Science, Technology and Innovation Malaysia (grant number: 549307).

\section{Availability of data and materials}

The data used and analyzed in this study are available from the corresponding author on reasonable request.

\section{Ethics approval and consent to participate}

This study was approved by the Institutional Animal Care and Use Committee, Universiti Putra Malaysia (UPM), Malaysia (Ref: AUP/ R095/2014), and animals were handled according to international animal welfare standards.

\section{Consent for publication}

Not applicable.

\section{Competing interests}

The authors declare that they have no competing interests.

\section{Author details}

${ }^{1}$ Department of Biomedical Sciences, Faculty of Medicine and Health Sciences, Universiti Putra Malaysia, Serdang, Selangor, Malaysia. ${ }^{2}$ Chengde Medical University, Chengde, Hebei, China. ${ }^{3}$ Department of Pathology, Faculty of Medicine and Health Sciences, Universiti Putra Malaysia, Serdang, Selangor, Malaysia. ${ }^{4}$ Key Laboratory of Plant Resources Conservation and Sustainable Utilization, Guangdong Provincial Key Laboratory of Applied Botany, South China Botanical Garden, Chinese Academy of Sciences, Guangzhou, China. ${ }^{5}$ Department of Pathology, Faculty of Veterinary Science, Bangladesh Agricultural University, Mymengsingh, Bangladesh. ${ }^{6}$ Nutrition Unit, Product Development and Advisory Services Division, Malaysian Palm Oil Board, Bandar Baru Bangi, Selangor, Malaysia.

Received: 22 November 2019 Accepted: 8 January 2020

Published online: 12 March 2020

\section{References}

Barrientos S, Stojadinovic O, Golinko MS, Brem H, Tomic-Canic M. Growth factors and cytokines in wound healing. Wound Repair Regen. 2008;16(5):585-601. https://doi.org/10.1111/j.1524-475X.2008.00410.x.

Birkedal-Hansen H. Proteolytic remodeling of extracellular matrix. Curr Opin Cell Biol. 1995;7(5):728-35. https://doi.org/10.1016/0955-0674(95)80116-2.

De S, Fenton JE, Jones AS. Matrix metalloproteinases and their inhibitors in nonneoplastic otorhinolaryngological disease. J Laryngol Otol. 2005;119(6):43642. https://doi.org/10.1258/0022215054273269.

Enoch S, Leaper DJ. Basic science of wound healing. Surgery. 2005;26:31-7. https://doi.org/10.1016/j.mpsur.2007.11.005.

Fingleton B. MMPs as therapeutic targets - still a viable option? Semin Cell Dev Biol. 2008;19(1):61-8. https://doi.org/10.1016/.semcdb.2007.06.006.

Grinnell F. Fibroblasts, myofibroblasts, and wound contraction. J Cell Biol. 1994; 124:401-4. https://doi.org/10.1083/jcb.124.4.401.

Guo H-F, Mohd Ali R, Abd Hamid R, Zaini AA, Khaza'ai H. A new model for studying deep partial-thickness burns in rats. Int J Burns Trauma. 2017;7(6):107-14.

Guzik TJ, Korbut R. Nitric oxide and superoxide in inflammation and immune regulation. J Physiol Pharmacol. 2003;54(4):469-87.

Harper D, Young A, McNaught CE. The physiology of wound healing. Surgery (Oxford). 2014;32(9):445-50.

Infanger M, Schmidt O, Kossmehl P, Grad S, Ertel W, Grimm D. Vascular endothelial growth factor serum level is strongly enhanced after burn injury and correlated with local and general tissue edema. Burns. 2004;30(4):305-11. https://doi.org/10.1016/.burns.2003.12.006.

Kagan RJ, Peck MD, Ahrenholz DH, Hickerson WL, Holmes J, Korentager R, Kraatz J, Pollock K, Kotoski G. Surgical management of the burn wound and use of skin substitutes: an expert panel white paper. 2009. J Burn Care Res. 2009;34:e60-79.

Kubo H, Hayashi T, Ago K, Ago M, Kanekura T, Ogata M. Temporal expression of wound healing-related genes in skin burn injury. Legal Med. 2014;16:8-13. https://doi.org/10.1016/j.legalmed.2013.10.002.

Lambert E, Dassé E, Haye B, Petitfrère E. TIMPs as multifacial proteins. Crit Rev Oncol Hematol. 2004;49(3):187-98. https://doi.org/10.1016/j.critrevonc.2003. 09.008 .

Lawrence T. The nuclear factor NF-kappaB pathway in inflammation. Cold Spring Harb Perspect Biol. 2009;1:1-10. https://doi.org/10.1101/cshperspect.a001651.

Li L, Chen J, Kirsner R. Pathophysiology of acute wound healing. Clin Dermatol. 2007;25:9-18. https://doi.org/10.1016/j.clindermatol.2006.09.007.

Lin Y-H, Huang C-C, Wang S-H. Quantitative assessments of burn degree by highfrequency ultrasonic backscattering and statistical model. Phys Med Biol. 2011;56:757-73. 
Midwood KS, Williams LV, Schwarzbauer JE. Tissue repair and the dynamics of the extracellular matrix. Int J Biochem Cell Biol. 2004;36(6):1031-7.

Monstrey S, Hoeksema H, Verbelen J, Pirayesh A, Blondeel P. Assessment of burn depth and burn wound healing potential. Burns. 2008:34:761-9. https://doi. org/10.1016/j.burns.2008.01.009 https://doi.org/10.1097/BCR. ob013e31827039a6.

Oberyszyn TM. Inflammation and wound healing. Front Biosci. 2008;12:2993-9. https://doi.org/10.2741/2289.

Pappas A. Lipids and skin health. 1st ed. New York: Springer International Publishing; 2015. p. 1-359. https://doi.org/10.1007/978-3-319-09943-9.

Parihar A, Parihar MS, Milner S, Bhat S. Oxidative stress and anti-oxidative mobilization in burn injury. Burns. 2008;34(1):6-17. https://doi.org/10.1016/j. burns.2007.04.009.

Park JE, Adrian Barbul MD. Understanding the role of immune regulation in wound healing. Am J Surg. 2004;187:2-7. https://doi.org/10.1016/500029610(03)00296-4.

Penn JW, Grobbelaar AO, Rolfe KJ. The role of the TGF- $\beta$ family in wound healing, burns and scarring: a review. Int I Burns Trauma. 2012;2(1):18-28.

Singer AJ, Clark RAF. Cutaneous wound healing. N Engl J Med. 1999;2:738-46. https://doi.org/10.1056/NEJM199909023411006.

Spies M, Dasu MR, Svrakic N, Nesic O, Barrow RE, Perez-Polo JR, Herndon DN. Gene expression analysis in burn wounds of rats. Am J Physiol Regul Integr Comp Physiol. 2002;283:R918-30. https://doi.org/10.1152/ajpregu.00170.2002. Stamenkovic I. Extracellular matrix remodelling: the role of matrix metalloproteinases. J Pathol. 2003;200(4):448-64. https://doi.org/10.1002/path. 1400.

Velnar T, Bailey T, Smrkolj V. The wound healing process: an overview of the cellular and molecular mechanisms. J Int Med Res. 2009;37:1528-42. https:// doi.org/10.1177/147323000903700531.

Wang X, McCullough KD, Franke TF, Holbrook NJ. Epidermal growth factor receptor-dependent Akt activation by oxidative stress enhances cell survival. J Biol Chem. 2000;75(19):14624-31. https://doi.org/10.1074/jbc.275.19.14624.

Werner S, Grose R. Regulation of wound healing by growth factors and cytokines. Physiol RevPhysiol Rev. 2003;83:835-70. https://doi.org/10.1152/ physrev.2003.83.3.835.

\section{Publisher's Note}

Springer Nature remains neutral with regard to jurisdictional claims in published maps and institutional affiliations.

Ready to submit your research? Choose BMC and benefit from:

- fast, convenient online submission

- thorough peer review by experienced researchers in your field

- rapid publication on acceptance

- support for research data, including large and complex data types

- gold Open Access which fosters wider collaboration and increased citations

- maximum visibility for your research: over $100 \mathrm{M}$ website views per year

At $\mathrm{BMC}$, research is always in progress.

Learn more biomedcentral.com/submissions 